\title{
KADAR LOGAM BERAT Pb (TIMBAL) SUSU KAMBING YANG DIBERI PAKAN SILASE LIMBAH SAYURAN
}

\author{
Pb Heavy Metal Content of Milk from Goat whom was Fed by Vegetables Waste Silage
}

\author{
A. Falahudin dan U.I.L. Rahmah
}

Major of Animal Husbandry, Faculty of Agriculture, Majalengka University

K.H. Abdul Halim No. 103 Majalengka

e-mail : aaffalahudin@ymail.com

\begin{abstract}
The aim of this research is to get information of heavy metal content of $\mathrm{Pb}$ in goat milk fed with vegetables waste silage which is safe to be consumed by society. The experiments were carried out by using 16 pregnant 2 - 2,5 years old goat who were treated until the mother was lactated. The experimental design used was Completely Randomized Design with 4 treatments and 4 replications. The treatments applied were as follows: T0 $=100 \%$ forage (mixture of grass and legume), $\mathrm{T1}=80 \%$ forage $+20 \%$ vegetables waste silage, $T 2=60 \%$ forage $+40 \%$ silage vegetables waste, and $\mathrm{T} 3=40 \%$ forage $+60 \%$ waste silage vegetables. The experiment was conducted for 5 months. The research results show that the feed silage vegetables waste very real produce milk production daily higher than the control of grass. The provision of silage vegetables waste very real produce metal Pb levels higher than control and be above threshold SNI 3141.1: 2011. So that it can be concluded that the silage vegetables waste not advisable done by farmers due to metal $\mathrm{Pb}$ in goat milk is still not safe to be consumed.
\end{abstract}

Keywords : Silage, Vegetables Waste, $\mathrm{Pb}$ (Lead), Goat Milk.

\section{PENDAHULUAN}

Prospek pengembangan produk susu kambing di Indonesia cukup potensial. Hal ini ditunjukkan dengan permintaan pasar yang tinggi. Permintaan tersebut belum dapat terpenuhi akibat produksi yang masih terbatas. Harga jual produk susu kambing juga cukup tinggi (Rp. $35.000 \quad-45.000 /$ liter). Hal ini dikarenakan susu kambing dinilai sebagai produk yang istimewa dengan berbagai manfaat dan khasiat - khasiatnya. Susu kambing ternyata juga sangat digemari konsumen dari luar negeri, sehingga hal ini akan berpeluang dijadikan sebagai komoditas ekspor (Setiawan dan Tarsius, 2005).

Peternakan kambing perah sangat berpotensi untuk dikembangkan. Usaha peternakan kambing perah sangat bergantung pada produktivitas hijauan pakan yang menentukan keberhasilan dari peternakan tersebut. Pada saat musim kemarau, hijaun pakan sangat sedikit bahkan tidak ada sehingga peternakan kambing dapat mengalami penurunan produktivitasnya. Salah satu potensi pakan pengganti hijaun yang belum termanfaatkan adalah limbah sayuran.

Salah satu kendala pemanfaatan limbah sayuran untuk dijadikan pakan adalah kandungan logam berat $\mathrm{Pb}$ (Timbal) yang cukup tinggi (10,58 - 13,74 ppm). Kandungan $\mathrm{Pb}$ tersebut melebihi ambang batas kandungan $\mathrm{Pb}$ sayuran yaitu 10 ppm yang ditetapkan SNI dan Balai Pengawasan Obat dan Makanan. Batas maksimal cemaran logam berbahaya dalam susu sapi segar direkomendasikan menurut Standar Nasional Indonesia No. 3141.1:2011 adalah Pb: $0,02 \mu \mathrm{g} / \mathrm{ml}$. Pemerintah telah menetapkan standar khusus untuk suatu produk. Indonesia saat ini baru mempunyai standard untuk susu sapi segar yang tercantum dalam SNI 3141.1:2011, sedangkan khusus untuk susu kambing segar belum mempunyai standar.

Pakan merupakan salah satu faktor yang dapat mempengaruhi komposisi kimiawi susu. Pemberian pakan dari limbah sayuran dapat mempengaruhi komposisi kimiawi susu. Oleh karena itu, perlu dilakukan penelitian untuk mengetahui ada atau tidaknya dan berapa kadar $\mathrm{Pb}$ dalam susu kambing yang diberi pakan limbah sayuran yang sesuai dengan Standar Nasional Indonesia No. 3141.1:2011. Penelitian ini bertujuan mendapatkan informasi kadar logam berat $\mathrm{Pb}$ (Timbal) dalam susu kambing yang diberi pakan silase limbah sayuran yang aman dikonsumsi oleh masyarakat. Hasil penelitian ini diharapkan bermanfaat bagi peternak dalam mendapatkan pakan alternatif 
yang murah dan dapat meningkatkan pendapatan peternak, tetapi susu yang dihasilkan aman untuk dikonsumsi. Selain itu juga diharapkan bermanfaat bagi pemerintah daerah sebagai salah satu cara pengelolaan sampah pasar untuk mengurangi pencemaran lingkungan dan beban TPA.

\section{MATERI DAN METODE}

\section{Materi}

Penelitian ini menggunakan 16 ekor kambing PE umur $2-2,5$ tahun yang sedang bunting yang ditempatkan dalam kandang individual berukuran $1,5 \times 1 \mathrm{~m}^{2}$ dan dilengkapi dengan tempat pakan dan minum. Bahan yang digunakan adalah larutan standar logam timbal dengan konsentrasi 1000 ppm, asam nitrat 1:1, asam klorida 1:1, aquabidestillata, gas yang digunakan pada sumber nyala spektrofotometri serapan atom untuk logam timbal.

Alat yang digunakan adalah perlengkapan pemerahan dan spektrofotometer serapan atom untuk mengukur kadar $\mathrm{Pb}$. Variabel yang diamati adalah produksi susu harian dan kadar $\mathrm{Pb}$ dalam susu kambing.

\section{Metode}

Penelitian dilaksanakan dengan metode eksperimen yang disusun berdasarkan Rancangan Acak Lengkap (RAL) dengan 4 perlakuan dan 4 ulangan. Perlakuan yang diterapkan adalah sebagai berikut :

$\mathrm{T} 0=100 \%$ hijauan (campuran rumput dan legume)

$\mathrm{T} 1=80 \%$ hijauan $+20 \%$ silase limbah sayuran

$\mathrm{T} 2=60 \%$ hijauan $+40 \%$ silase limbah sayuran

$\mathrm{T} 3=40 \%$ hijauan $+60 \%$ silase limbah sayuran

Kegiatan penelitian dimulai dengan persiapan kandang terlebih dahulu menggunakan kandang individual ukuran 1,5 x $1 \mathrm{~m}^{2}$. Dilanjutkan dengan pembersihan kandang dan peralatan lainnya seperti tempat makan dan minum. Kambing ditempatkan di dalam kandang individual dan diberikan pakan biasanya berupa rumput.

Selanjutnya dilakukan pembuatan silase dengan menggunakan starter EM-4 sebanyak 5 $\mathrm{ml}$ (medium cair), dan aditif molase 3\% serta dedak padi sebanyak $30 \%$, diperam (difermentasi) selama 7 hari. Proses pembuatan silase selengkapnya dapat dilihat di bawah ini.
Proses pembuatan silase pada limbah sayuran pasar menurut Saenab dan Retnani (2011) antara lain sebagai berikut:

1. Pemilahan, pemisahan, dan pembersihan/ pencucian limbah sayuran pasar.

2. Limbah sayuran pasar dicacah/dipotongpotong dengan ukuran $3-4 \mathrm{~cm}$.

3. Pencampuran dengan bahan-bahan aditif berupa dedak padi sebanyak $30 \%+$ molase sebanyak $3 \%+5$ cc probiotik, dan diaduk sampai merata. Bahan aditif yang ditambahkan berfungsi untuk meningkatkan kadar protein atau karbohidrat pada bahan pakan.

4. Kemudian bahan yang telah tercampur rata dimasukkan ke dalam silo yang terbuat dari plastik sedikit demi sedikit sambil dilakukan pemadatan (sambil diinjak-injak) agar tidak ada lagi udara diantara tumpukan bahan silase, lalu ditutup rapat.

5. Silo ditempatkan di tempat yang sejuk untuk proses fermentasi selama 1 minggu.

6. Setelah silase jadi dapat dikeluarkan dari silo untuk diberikan pada ternak. Sebelum diberikan pada ternak perlu dianginanginkan atau dibiarkan terlebih dahulu selama beberapa jam.

7. Silase yang berkualitas baik memenuhi persyaratan antara lain mempunyai $\mathrm{pH}$ sekitar 4, kandungan air berkisar antara 60 $70 \%$, berbau segar dan tidak berbau busuk, warna hijau masih jelas pada bahan hijauan, tidak berlendir, serta tidak berbau tengik. Silase dapat disimpan untuk jangka waktu lama selama tidak ada udara yang masuk ke dalam silo.

Pemberian pakan baik hijauan rumput atau silase limbah sayuran pasar dilakukan dua kali setiap hari yaitu pada pagi dan sore hari. Air minum diberikan secara ad libitum. Kambing PE diadaptasikan pada perlakuan pakan selama $3-4$ bulan (saat kambing bunting) dan setelah kambing laktasi (menyusui) dilakukan pengambilan data berupa susu segar. Parameter yang diukur meliputi produksi susu harian dan kadar $\mathrm{Pb}$ susu kambing.

Semua data yang diperoleh dianalisis secara statistik menggunakan analisis ragam (analysis of variance) dengan bantuan program SPSS versi 16 dan apabila ada perbedaan antar perlakuan dilanjutkan dengan Uji lanjut Duncan (Steel dan Torrie, 1993). 


\section{HASIL PENELITIAN}

\section{Produksi Susu}

Pengamatan dilakukan setelah kambing tersebut melahirkan dan masuk pada masa laktasi (menyusui). 7 hari pertama susu kolostrum diberikan untuk anak kambing (cempe). Setelah itu, cempe diberikan susu pengganti berupa susu sapi segar secukupnya. Selanjutnya setelah minggu pertama kolostrum, dilakukan pengamatan produksi susu harian. Pemerahan susu kambing dilakukan sebanyak 2 kali yaitu pagi dan sore hari. Produksi susu pada pemerahan pagi lebih banyak dibandingkan dengan pemerahan pada sore hari. Pengamatan produksi susu kambing dilakukan selama 30 hari pertama laktasi (liter/ekor/hari). Rataan produksi susu 30 hari pertama laktasi dapat dilihat pada Tabel 1.

Tabel 1. Rataan Produksi Susu 30 Hari Pertama Laktasi (1/ekor/hari)

\begin{tabular}{clc}
\hline Perlakuan & Rata - rata \\
\hline T0 & $0,99^{\mathrm{a}}$ \\
T1 & $1,27^{\mathrm{b}}$ \\
T2 & $1,35^{\mathrm{b}}$ \\
T3 & $1,63^{\mathrm{c}}$ \\
\hline Keterangan : & Superskrip huruf yang berbeda \\
& pada kolom yang sama \\
& menunjukkan perbedaan yang \\
& nyata $(\mathrm{P}<0,05)$ &
\end{tabular}

Hasil analisis ragam berdasarkan Tabel 1 menunjukkan bahwa substitusi pakan silase limbah sayuran berbeda nyata $(\mathrm{P}<0,05)$ terhadap produksi susu harian. Hal tersebut menunjukkan bahwa pemberian silase limbah sayuran pada kambing perah dapat meningkatkan produksi susu harian.

Berdasarkan Tabel 1 menunjukkan bahwa substitusi pakan silase limbah sayuran dapat meningkatkan produksi susu harian. Hal tersebut dikarenakan kandungan protein silase limbah sayuran lebih tinggi dibandingkan dengan hijauan rumput. Hasil analisis proksimat menunjukkan bahwa limbah sayur pasar tradisional memiliki kandungan protein kasar 12,64 - 23.50\% (Muktiani et al., 2007). Protein tersebut akan dimetabolisasi oleh tubuh dan digunakan sebagai bahan baku sintetis enzim, hormon dan produksi susu sehingga produksi susu kambing berbanding lurus dengan konsumsi proteinnya (Muktiani et al., 2013).

Rataan produksi susu harian kambing PE pada penelitian ini baik kontrol (100\% hijauan) maupun yang diberi substitusi silase limbah sayuran $20 \%, 40 \%$ dan $60 \%$ adalah berturut turut 0,$99 ; 1,27 ; 1,35$ serta 1,63 1/ekor/hari.
Sutama $d k k$. (1995) yang disitasi oleh Sutama dan Budiarsana (1997) menginformasikan bahwa produksi susu kambing PE masih sangat bervariasi yaitu $0,45-2,2$ liter/hari.

Secara umum rataan produksi susu kambing PE ini lebih rendah dari produksi susu kambing perah di daerah sub-tropis seperti kambing Saanen, British Alpine, Toggenburg, Anglo Nubian, yang khusus diseleksi sebagai ternak perah. Kambing tersebut dapat menghasilkan susu 5-6 liter/ekor/hari pada kambing produksi tinggi atau sekitar 2 - 3 liter/ekor/llari bagi kebanyakan kambing perah (Stemmer, 1991 dalam Sutama dan Budiarsana, 1997).

Hasil uji lanjut Duncan menunjukkan bahwa pemberian atau substitusi pakan silase limbah sayuran $60 \%$ dapat menghasilkan produksi susu harian paling tinggi dibandingkan dengan substitusi silase limbah sayuran 20 dan $40 \%$. Hal tersebut menunjukkan bahwa semakin banyak silase limbah sayuran yang diberikan maka produksi susu harian pada kambing perah semakin tinggi.

\section{Kadar Logam Berat Pb (Timbal)}

Uji kadar logam berat $\mathrm{Pb}$ (Timbal) dilaksanakan di Laboratorium Jasa Uji Fakultas Teknologi Industri Pertanian Universitas Padjadjaran. Hasil uji kadar logam Timbal (Pb) pada susu kambing yang diberi pakan silase limbah sayuran dapat dilihat pada Tabel 2.

Tabel 2. Rataan Kadar Logam Pb (Timbal) Susu Kambing (ppm)

\begin{tabular}{crr}
\hline Perlakuan & Rata - rata \\
\hline T0 & $0,2049^{\mathrm{a}}$ \\
T1 & $0,2517^{\mathrm{b}}$ \\
T2 & $0,3160^{\mathrm{c}}$ \\
T3 & $0,3281^{\mathrm{d}}$ \\
\hline Keterangan : & Superskrip huruf yang berbeda \\
& pada kolom yang sama \\
\multicolumn{2}{c}{ menunjukkan perbedaan yang } \\
nyata $(\mathrm{P}<0,05)$ & &
\end{tabular}

Hasil analisis ragam berdasarkan Tabel 2 menunjukkan bahwa substitusi pakan silase limbah sayuran pada kambing perah berbeda nyata $(\mathrm{P}<0,05)$ terhadap kadar logam berat $\mathrm{Pb}$ susu kambing. Hal tersebut menunjukkan bahwa pemberian silase limbah sayuran pada kambing perah dapat meningkatkan kadar logam berat $\mathrm{Pb}$ pada susu kambing.

Berdasarkan Tabel 2 menunjukkan bahwa substitusi pakan silase limbah sayuran dapat meningkatkan kadar logam berat $\mathrm{Pb}$ pada susu kambing. Hal tersebut dikarenakan kadar 
logam berat $\mathrm{Pb}$ pada limbah sayuran lebih tinggi dibandingkan dengan hijauan rumput.

Rataan kadar logam berat $\mathrm{Pb}$ susu kambing pada penelitian ini baik kontrol (100\% hijauan) maupun yang diberi substitusi silase limbah sayuran 20\%, 40\% dan $60 \%$ adalah berturut - turut 0,$2049 ; 0,2517 ; 0,3160$ serta 0,3281 ppm. Hal tersebut menunjukkan bahwa semakin tinggi pemberian silase limbah sayuran maka semakin tinggi pula kadar logam $\mathrm{Pb}$ pada susu kambing. Kadar logam berat $\mathrm{Pb}$ baik kontrol maupun yang diberi substitusi silase limbah sayuran sudah berada di atas ambang batas SNI 3141.1:2011 yaitu 0,02 ppm. Akan tetapi, jika dibandingkan dengan SNI 013141:1998 perlakuan kontrol dan substitusi silase limbah sayuran $20 \%$ masih berada di bawah ambang batas yaitu $0,3 \mathrm{ppm}$.

Tingginya kadar $\mathrm{Pb}$ susu kambing yang berasal dari hijauan rumput disebabkan lokasi tempat tumbuhnya rumput berada dekat dengan jalan raya yaitu sekitar $2-3 \mathrm{~m}$ dari jalan raya. Sedangkan tingginya kadar $\mathrm{Pb}$ susu kambing yang berasal dari silase limbah sayuran karena bahan silasenya berasal dari limbah sayuran pasar tradisional yang kondisinya kotor. Selain itu, limbah sayuran dibuang dan diletakkan di atas aspal dan bercampur dengan sampah lain seperti kertas koran dan debu jalanan yang mengandung logam $\mathrm{Pb}$. Antari et al. (2002) menyatakan bahwa pencemaran logam $\mathrm{Pb}$ pada sayuran dapat terjadi sama seperti rumput yaitu akibat tanah, air dan udara yang tercemar. Kendaraan bermotor merupakan sumber pencemar utama logam $\mathrm{Pb}$ di udara. Selain itu, rumput dapat tercemar logam $\mathrm{Pb}$ melalui penyerapan akar dari tanah atau melalui stomata daun dari udara.

\section{SIMPULAN DAN SARAN}

\section{Simpulan}

1. Pemberian pakan silase limbah sayuran telah nyata menunjukkan hasil rataan produksi susu harian kambing yang lebih tinggi dibandingkan dengan kontrol.

2. Kadar logam $\mathrm{Pb}$ (Timbal) susu kambing baik yang diberi rumput maupun substitusi silase limbah sayuran tidak aman untuk dikonsumsi karena tidak sesuai dengan Standar Nasional Indonesia No. 3141.1:2011.

\section{Saran}

Berdasarkan hasil penelitian maka tidak disarankan pemberian pakan silase limbah sayuran diaplikasikan oleh peternak dikarenakan tingginya kadar logam $\mathrm{Pb}$ pada susu kambing. Perlu penelitian lebih lanjut mengenai upaya untuk mengurangi kadar $\mathrm{Pb}$ pada susu dengan cara suplementasi alginat maupun mineral $\mathrm{Zn}$ dan $\mathrm{Cr}$.

\section{DAFTAR PUSTAKA}

Antari A. A. R. J. dan K. Sundra. 2002. Kandungan Timah Hitam (Plumbum) pada Tanaman Peneduh Jalan di Kota Denpasar. Fakultas Matemetika dan Ilmu Pengetahuan Alam. Universitas Udayana, Bali.

Badan Standardisasi Nasional. 2011. SNI 3141.1:2011. Susu Segar. BSN. Jakarta.

Muktiani, A., J. Achmadi dan B. I. M. Tampubolon. 2007. Fermentabilitas Rumen Secara In Vitro Terhadap Sampah Sayur Yang Diolah. Jurnal Pengembangan Peternakan Tropis 32 (1) : 44-50.

Muktiani, A., J. Achmadi, B. I. M. Tampoebolon dan R. Setyorini. 2013. Pemberian Silase Limbah Sayuran yang Disuplementasi dengan Mineral dan Alginat Sebagai Pakan Domba. Jurnal Ilmu dan Teknologi Peternakan 3(2): 144-151.

Saenab, A. dan Y. Retnani. 2011. Beberapa model teknologi pengolahan limbah sayuran pasar sebagai pakan alternatif pada ternak (Kambing/ Domba) di perkotaan. BPTP Jakarta. Jakarta.

Setiawan, T., dan A. Tarsius. 2005. Beternak Kambing Perah Peranakan Etawa. Penebar Swadaya. Jakarta.

Steel, R.G.D. dan J.H. Torrie. 1993. Prinsip dan Prosedur Statistik Suatu Pendekatan Biometrik. Edisi Kedua, Gramedia, Jakarta. (Diterjemahkan oleh Bambang Sumantri).

Sutama, I.K. dan I.G.M. Budiarsana. 1997. Kambing Peranakan Etawah Penghasil Susu sebagai Sumber Pertumbuhan Baru Sub-Sektor Peternakan di Indonesia. Seminar Nasional Peternakan dan Veteriner. Bogor. 